\title{
INTRODUCING THE NEW CONFIGURATION BETWEEN STATE, CIVIL SOCIETY AND THE MARKET ${ }^{1}$
}

Michel Bauwens with contribution from John Restakis.

\begin{abstract}
The following text is an excerpt from the Commons Transition Plan that was produced on behalf of the three Ecuadorian public institutions which financed the floksociety.org transition project, which aimed (aims) to create a social knowledge economy, i.e. an economy based on free, libre, open knowledge (FLOK), and which took place in 2014 with the aim of implementing legislation and pilot projects. The generic transition plan is available at http://en.wiki.floksociety.org/w/Research_Plan and is accompanied by $15+$ concrete subject-specific legislative frameworks, which can be consulted here at https://floksociety.co-ment.com/.
\end{abstract}

Keywords

Peer production. Open knowledge. Knowledge economy.

\section{INTRODUÇÃO A UMA NOVA CONFIGURAÇÃO ENTRE ESTADO, SOCIEDADE CIVIL E MERCADO}

\section{Resumo}

Esse artigo é um trecho do Plano de Transição Commons, que foi produzido em nome das três instituições públicas equatorianos que financiaram o projeto floksociety.org cujo objetivo é criar uma economia do conhecimento social, ou seja, uma economia baseada no livre e no conhecimento aberto. O projeto aconteceu em 2014 com o objetivo de implementar a legislação e abrigar projetos-piloto. O plano de transição está disponível em http://en.wiki.floksociety.org/w/Research_Plan e é acompanhado por 15 quadros legislativos específicos de um assunto concreto, que podem ser consultados em https://floksociety.co-ment.com/.

Palavras-chave

Produção entre pares. Conhecimento aberto. Economia do conhecimento.

\section{INTRODUCTION}

The social knowledge economy is not an utopia, or just a project for the future. It is rooted in an already existing social and economic practice, that of commons-oriented peer production, which is already producing commons of knowledge, code, and design, and it has produced real economies like the free software economy, the open hardware economy, the free culture economy, etc... In its most broad interpretation, concerning all the economic activities that are emerging around open and shared knowledge, it may have reached already 1/6th of GDP in the USA, employing 17 million workers, according to the Fair Use Economy report.

A lot is known about the micro-economic structures of this emerging economic model,

\footnotetext{
${ }^{1}$ Written in the capacity of research director of the floksociety.org project at the IAEN in Quito, Ecuador.
} 
which we can summarize as follows:

- At the core of this new value model are contributory communities, consisting of both paid and unpaid labour, which are creating common pools of knowledge, code, and design. These contributions are enabled by collaborative infrastructures of production, and a supportive legal and institutional infrastructure, which enables and empowers the collaborative practice;

- These infrastructures of cooperation, i.e. technical, organizational, and legal infrastructures, are very often enabled, certainly in the world of free software commons, by democratically-run Foundations, sometimes called FLOSS Foundations, or more generically, 'for-benefit associations', which may create code depositories, protect against infringements of the open and sharing licenses, organize fundraising drives for the infrastructure, and organize knowledge sharing through local, national and international conferences. They are an enabling and protective mechanism.

- Finally, the successful projects create a economy around the commons pools, based on the creation of added value products and services that are based on the common pools, but also add to it. This is done by entrepreneurs and businesses that operate on the marketplace, and are most often for-profit entreprises, creating a 'enterpreneurial coalition' around the common pools and the community of contributors. They hire the developers and designers as workers, create livelihoods for them, and also support the technical and organisational infrastructure, including also the funding of the Foundations.

On the basis of this generic micro-economic experiences it is possible to deduce adapted macro-economic structures as well, which would consist of a civil society that consists mainly of communities of contributors, creating shareable commons; of a new partner state form, which enables and empowers social production generally and creates and protects the necessary civic infrastructures; and an enterpreneurial coalition which conducts commerce and create livelyhoods.

\section{The new configuration}

In the old neoliberal vision, value is created in the private sector by workers mobilized by capital; the state becomes a market state protecting the privileged interests of property owners; and civil society is a derivative rest category, as is evidenced in the use of our language (non-profits, non-governmental). Nevertheless, the combination of labor and civic movements has partially succeeded in socialising the market, achievements which are now 
under threat.

In the new vision of cognitive capitalism, the networked social cooperation consists of mostly unpaid activities that can be captured and financialized by proprietary 'network' platforms. Social media platforms almost exclusively capture the value of the social exchange of their members, and distributed labor such as crowdsourcing more often than not reduce the average income of the producers. In other words, the 'netarchical' version of networked production creates a permanent precariat and reinforces the neoliberal trends.

In the contrary vision of a open-commons based knowledge economy and society, value is created by citizens, paid or voluntary, which create open and common pools of knowledge, co-produced and enabled by a Partner State, which creates the right conditions for such open knowledge to emerge; and preferentially ethical enterpreneurial coalitions which create market value and services on top of the commons, which they are co-producing as well. The ideal vision of an open-commons based knowledge economy is one in which the 'peer producers' or commoners (the labor form of the networked knowledge society), not only cocreate the common pools from which all society can benefit, but also create their own livelyhoods through ethical enterprise and thereby insure not only their own social reproduction but also that the surplus value stays within the commons-cooperative sphere. In this vision, the social solidarity economy is not a parallel stream of economic production, but the hyper-productive and hyper-cooperative core of the new economic model.

Thus in the new vision, civil society can be seen as consisting as a series of productive civic commonses, common pools of knowledge, code and design; the market consists of preferentially actors of the cooperative, social and solidarity economy which integrate the common good in their organizational structures, and whose labor-contributing members coproduce the commons with the civic contributors. Finally, in this vision, the Partner State enables and empowers such social cooperation, and creates the necessary civic and physical infrastructures for this flowering of innovation and civic and economic activity to occur.

The Partner State is not a weak neoliberal state, which strips public authority of its social functions, and retains the market state and repressive functions, as in the neoliberal model; it is also not the Welfare State, which organizes everything for its citizens; but it is a state that builds on the welfare state model, but at the same time creates the necessary physical and civic infrastructures for social autonomy, and for a civic production model that combines civic immaterial commons and cooperative social solidarity enterprise.

The ethical economy and market, is not a weak and parallel economy that specializes in the less competitive sectors of the economy; on the contrary, the ethical market is the core 
productive sector of the economy, building strong enterprises around competitive knowledge bases. It is however, at the service of civil society and co-construct the open knowledge commons on which society and commerce depends.

\section{Why is this a post-capitalist scenario?}

Capitalist-driven societies produce for exchange value, which may be useful, or not; and continuously strives to create new social desires and demands.

By way of contrast, the open-commons based knowledge economy consists a productive civil society of contributors, citizen contributors who continuously contribute to the commons of their choice based on use value motivations; it is around these use-value commons that an ethical market and economy finds its place, and creates added value for the market. The commons is continuously co-produced by both citizen contributors and paid ethical labor from the cooperative / social sector. In this scenario, the primary driver is the sphere of abundance of knowledge available for all, which is not a market driven by supply and demand dynamics; but around the immaterial abundance of non-rival or even anti-rival goods, is deployed a market of cooperatives and social solidarity players which add and sell scarce resources on the marketplace.

In this same scenario, the state is no longer a neoliberal market-state at the service of property owners, but is at the service of civil society, their commons, and the sphere of the ethical economy. It is not at the service of the private capital accumulation of property owners, but is at the service of the value accumulation and equitable value distribution taking place in the commons-cooperative sector. It is at the service of the buen vivir of its citizens, and the good knowledge they need for this. Instead of a focus on public-private partnerships, which excludes participation from civil society; a commons-supporting partner state will look at the development of public-social or public-commons partnerships. Where appropriate the Partner State looks at the possible commonification of public services. For example, following the model of Quebec and Northern Italy in creating Solidarity Cooperatives for Social Care, in which the state enables, regulates the direct provision of care by multistakeholder governed civil society based organisations. It is very likely that once the state undertakes the support of a commons-based civic and ethical economy in the sphere of knowledge, that it will also look at the development of institutional commons in the physical sphere. For example, developing commons-based housing development policies, which keep social housing outside of the speculative sphere. A society and state which desires to develop a commons in the immaterial sphere of knowledge, will also look at expanding the commons 
sphere in other spheres of human activity.

An example may show why this may be sometimes necessary. In the sphere of free software production, nearly all free software knowledge communities have their own forbenefit association which enables the cooperation, protects the licenses, etc. This is mostly likely because engagement requires knowledge and access to networks, which have been largely socialized in our societies. But open hardware developers have not developed such associations, and are more dependent on the companies selling hardware. This is because open hardware requires substantial material resources which need to be purchased privately, which favours the owners of capital and weakens the productive community that contributes to the commons. In such a scenario, the idea that open hardware developers could mutualize their means of production, would re-establish more balance between developers and company owners. Our illustration also mentions the commons-oriented ownership and governance forms which can assist citizens in having more control over crucial infrastructures such as land and housing.

\section{Discussion: The role of the capitalist sector. What is the role of the capitalist sector in such a scenario?}

The first key issue here is the creation of a level playing field between the social solidarity sector and the private sector. Whereas the social solidarity economy voluntarily integrates the common good in its statutes and operations, and is as it were 'naturally commons-friendly', the private capital sector is regulated so that its denial of social and environmental externalities is mitigated.

The Partner State encourages transitions from extractive to generative ownership models, while the association of private companies with the commons will assist them in adapting to the new emerging models of co-creation and co-design of value with the commoners. Hyper-exploitation of distributed labour will be mitigated through new solidarity mechanisms. As the mutual adaptation between the commons sector, the cooperative sector and the capitalist sector proceeds, the remaining capitalist sector should be increasingly socialized in the new practices, as well as ownership and governance forms. The aim is to create a level playing field, in which hyper-exploitation of social value becomes a gradual impossibility, and in which extractive rent-taking becomes equally impossible and counterproductive through the existence of well-protected open commons.

The second key issue concerns the self-reproduction capabilities of the commons 
contributors. Under the dominance of neoliberal, cognitive and netarchical capitalist forms, commoners are not able to create livelyhoods in the production of open knowledge commons, and under most open licenses, private companies are free to use and exploit the common knowledge without secure return. This obliges many and most commoners to work for private capital. What needs to be achieved is a new compact between the commons and the private companies, that insures the fair distribution of value, i.e. a flow of value must occur from the private companies to the commons and the commoners from whom the value is extracted. Models must be developed that allow privately owned companies to become fair partners of the commons. In the end, no privately-owned company, using its own research staff and proprietary IP, will be able to compete against open eco-systems that can draw on global knowledge production and sharing; this process of fair adaptation must be encouraged and accompanied by both measures from the commons and their associated ethical enterprises, and by the Partner State, in a context in which all players can benefit from the commons. Private capital must recognize, and must be made to recognize, that the value there are capturing comes overwhelmingly from the benefits of social cooperation in knowledge creation: just as they had to recognize the necessity for better and fair pay for labour, they must recognize fair pay for commons production.

\section{A description of the new triarchy of the Partner State, the Ethical Economy and a Commons-based Civil Society}

\section{The concept of the partner state and the commonification of public services}

Thus is born the concept of the Partner State, which is not opposed to the welfare state model, but 'transcends and includes' it. The Partner State is the state form which enables and empowers the social production of knowledge, livelihoods and well-being, by protecting and enabling the continuation and expansion of commons. The Partner State is the institution of the collectivity which creates and sustains the civic infrastructures and educational levels, and whose governance is based on participation and co-production of public services and collective decision-making. The Partner State retains the solidarity functions of the welfare state, but de-bureaucratizes the delivery of its services to the citizen. It abandons it paternalistic vision of citizens that are passive recipients of its services. The Partner State is therefore based on wide-spread participation in decision-making, but also in the delivery of its services. Public services are co-created and co-produced with the full participation of the citizens. 
The means to this end is the 'commonification of public services' through publiccommons partnerships. Public-private partnerships do not only add to the cost of public services, and create widespread distrust and need for control to counterbalance the profitinterests of the partners, but are essentially anti-democratic as they leave out the participation of the citizenry.

In a commentary, Silke Helfrich defines the general relationship of the state with the commons as such:

"For me the role of the state is at least fourfold:

not only

- to stop enclosures, but to trigger the production/construction of new commons by

- (co-) management of complexe resource systems which are not limited to local boundaries or specific communities (as manager and partner)

- $\quad$ survey of rules (chartas) to care for the commons (mediator or judge)

- $\quad$ kicking of or providing incentives for commoners governing their commons - here the point is to design intelligent rules which automatically protect the commons, like the GPL does (facilitator)".

David Bollier adds that:

"The State already formally delegates some of its powers to corporations by granting them corporate charters, ostensibly to serve certain public purposes. Why can't the state make similar delegations of authority to commons-based institutions, which would also (in their own distinct ways) serve public purposes? If the key problem of our time is the market/state duopoly, then we need to insist that the state authorize the self-organizing and legal recognition of commons-based institutions also. James Quilligan has called for commoners to create their own 'social charters', but the legal standing of such things remains somewhat unclear.

The public value of state-chartered commons-based institutions is that they would help:

1) Limit the creation of negative externalities that get displaced onto others (as corporations routinely do);

2) Declare certain resources to be inalienable and linked to communities as part of their identity;

3) Assure more caring, conscientious and effective stewardship and oversight of resources than the bureaucratic state is capable of providing; and

4) Help commoners internalize a different set of stewardship values, ethics, social 
practices and long-term commitments than the market encourages." (email, July 2012)

But it is Tommaso Fattori, a leading activist of the Italian Water Commons movement, which has the most developed concept of the commonification of public services:

"The field of Commons can be for the most part identified with a public but not-state arena, in which the actions of the individuals who collectively take care of, produce and share the Commons are decisive and fundamental.

In this sense, Commons and commoning can become a means for transforming public sector and public services (often bureaucracy-bound and used to pursue the private interests of lobby groups): a means for their commonification (or commonalization). Indeed, there are many possible virtuous crossovers between the traditional public realm and the realm of Commons.

Commonification goes beyond the simple de-privatization of the public realm: Commonification basically consists of its democratization, bringing back elements of direct self-government and self-managing, by the residents themselves, of goods and services of general interest (or participatory management within revitalized public bodies). Commonification is a process in which the inhabitants of a territory regain capability and power to make decisions, to orientate choices, rules and priorities, reappropriating themselves of the very possibility of governing and managing goods and services in a participatory manner: it is this first-person activity which changes citizens into commoners. Generally, there are a series of circumstances (including living space and time schedules, job precariousness and other difficult work conditions, the urbanization of land and the complexity of infrastructures) which do not physically allow the inhabitants of a large metropolis to completely self-manage fundamental services such as water utilities or public transport, bypassing the Municipalities and the public bodies (or managing without public funds to finance major infrastructure works): it is on the other hand possible to include elements of self-government and commoning in the distinct stages of general orientation, planning, scheduling, management and monitoring of the services. At the same time it is necessary to also give back public service workers an active role in co-management. Which means going the other way down the road as compared to the privatization of that which is "public".

But there are also other overlaps possible between the idea of public and that of Commons, apart from the necessary creation of legislative tools which can protect and encourage Commons and commoning.

Several forms of Public-Commons partership can be developed, where the role of state 
is realigned, from its current support and subsidising of private for-profit companies, towards supporting commoning and the creation of common value. This can be achieved through tax exemptions, subsidies and empowerment of sharing and commoning activities, but also, for example, by allocating public and state-owned goods to common and shared usage thanks to projects which see public institutions and commoners working together. This is a road which could be the beginning of a general transformation of the role of the state and of local authorities into partner state, "namely public authorities which create the right environment and support infrastructure so that citizens can peer produce value from which the whole of society benefits".

Tommaso Fattori has offered an in-depth understanding of the precise relationship between the new state form and the commons:

"To understand in what sense and under what conditions public services can be considered commons, it is necessary to offer some brief notes on what is meant by public service and what by commons. In both cases it is difficult to be concise, because of the breadth of the debate on the areas and the issues. Public Services. As is well known, in most legal systems, the laws do not provide any definition of what is meant by the concept 'public service'. In short, in the doctrinal reconstruction, there are two main positions: the subjective theory focuses attention on the public nature of the subject supplying the service, whereas the objective theory focuses attention on the public interest which distinguishes the activity performed. According to the subjective theory, the elements necessary to identify public service are the direct or indirect responsibility of the State or another public body for the service, and its supply for the benefit of its citizens. On the other hand, for the objective theory, the necessary element is that the service be provided to the collectivity and place public interest at its heart. The EU however prefers to duck the issue and speak of "services of general interest": services (both market and non-market) which are considered of central interest for the collectivity and that for this reason must be subjected to "specific obligations of public service". In these pages, by public services we mean the services of general interest, that is, that plethora of fundamental services which were once an integral part of welfare services but nowadays have mostly been privatized, following political decisions, or are supplied by public bodies but run along the lines of privatized companies. These services include, although this is not an exhaustive list, health services, schools and universities, power supply, transport and other local utilities such as the water or waste services.

Commons: The definition of what is meant by commons, and what commoning is, is more complex, as this is an area in which different approaches and paradigms clash. In very 
general terms, commons is everything we share; in particular gifts of nature and creations of society that belong to all of us equally, and should be preserved for future generations: material or immaterial, rival or non-rival, natural or artificial resources that elude the concept of exclusive use and build social bonds. In addition to shared resources, there are another two fundamental building blocks of the commons: commoners and commoning. Commoners are all the members of a community, or even loosely connected groups of people, who steward and care for the shared resources, or produce common resources, adopting a form of selfgovernment based on their capacity to give themselves rules (and incentives and sanctions to ensure they are respected, as well as mechanisms for monitoring and resolving conflicts), called commoning. Commoning is a participatory and inclusive form of decision-making and a governance system for sharing, producing and reproducing commons in the interest of present and future generations and in the interest of the ecosystem itself, where natural commons are concerned.

Still in general terms, although almost all goods and resources can potentially become objects of sharing, after a choice and decision by people, and thus become "shared resources" or "commons", it is however probable that most of humanity would agree on a nucleus of resources which, at least in principle, "cannot not be commons", on pain of denying life itself and the possibility of free individual and collective development: primary, fundamental, natural or social resources, which range from water to knowledge.3 A future without couchsurfing, where all beds are given a monetary value and not shared, is certainly less desirable than a future with couch-surfing; but a future without access to water for all is unacceptable. These primary commons must not allow discrimination in access to them according to individual wealth, reintroducing the element of equality and fairness, as well as a relationship of care - rather than one of domination or subjection - between humanity and the rest of nature of which it is a part. These are resources which do not belong to and which are not at the disposal of governments or the State-as-person, because they belong to the collectivity and above all, to future generations, who cannot be expropriated of their rights. Distributed participatory management and self-government, inclusion and collective enjoyment, no individual exclusive rights, prevalence of use value over exchange value, meeting of primary and diffuse needs: commons, in this understanding, means all these things."

One of the mechanisms for the delivery of commonified public services are through contracts between the state as funding and quality control mechanism, and "Solidarity cooperatives", which are multi-stakeholder coops, bringing together all parties involved in a 
particular endeavor-workers, consumers, producers and members of the larger community-in a democratic structure of ownership and control. This new system of delivery has been pioneered in the field of social care, for health and support services for particular populations such as the elderly, the physically handicapped etc... and is particularly strong in northern Italy (Emilia-Romagna, the region around Bologna), as well as in Quebec. The examples are described in the policy report from John Restakis.

\section{TO CONCLUDE}

In a mature social knowledge economy, he state will still exist, but will have a radically different nature. Much of its functions will have been taken over by commons institutions, but since these institutions care primarily about their own commons, and not the general common good, we will still need public authorities that are the guarantor of the system as a whole, and can regulate the various commons, and protect the commoners against possible abuses. So in our scenario, the state does not disappear, but is transformed, though it may greatly diminish in scope, and with its remaining functions thoroughly democratized and based on citizen participation. In our vision, it is civil-society based peer production, through the Commons, which is the guarantor of value creation by the private sector, and the role of the state, as Partner State, is to enable and empower the creation of common value. The new peer to peer state then, though some may see that as a contradictio in terminis, is a state which is subsumed under the Commons, just as it is now under the private sector.

Source: Excerpts from a text prepared by Tommaso Fattori as part of the book-project "Protecting Future Generations Through Commons", organized by Directorate General of Social Cohesion of the Council of Europe in collaboration with the International University College of Turin. The text will be published soon in "Trends in Social Cohesion" Series, Council of Europe publications.

\section{The Ethical Economy}

What exactly is the nature and the role of the ethical economy in the social knowledge economy?

First of all, the ethical economy "realizes" the value that is created by the 'commoners' in the common pools, by creating added value for the ethical market sector. The realized surplus goes directly to the workers who are also the contributors to the commons, thereby realizing their self-reproduction, independently of the classic capital accumulation economy. 
A new 'cooperative accumulation' process is thereby created that mediates between the commons and the classical capital sector, and directly serve the commons and the commoners.

The ethical economy can realize profits, but the realized profits serve a purpose, a mission, at the direct service of the creation of use value. It doesn't coincide therefore to the civic nonprofit sector, but is better called a Not-For-Profit sector, since the profits are subsumed to the social goal. This is in essence why the new sector is called an ethical economy, because the goals are not the accumulation of profit, but of 'benefits'. So a synonym is to talk about a 'for-benefit' sector.

The ethical companies, can take very different form, or 'open company formats', with their common goal being to contribute to the 'common good' generally, and to the commons specifically. They may be allied amongst themselves as enterpreneurial coalitions around certain specific common pools (but likely will use more than one commons). The different legal regimes may be B-Corporations, Fair Trade companies, social enterpreneurs, worker's or other form of cooperatives... One of the key innovations has been the development of 'Solidarity Cooperatives', whose emergence has been described elsewhere by John Restakis. Solidarity Coops integrate the common good in their statutes, and are multi-stakeholder governed.

The ethical economy may be focused on relocalized production for reasons of sustainability, but its workers cooperate globally directred through the open design communities that are essential for their operations. Organizationally, they can be globally organized through models like solidarity franchising, or "Phyles", i.e. through global community-supportive or mission-oriented ethical 'transnational' forms.

\section{Discussion: Material and Immaterial Infrastructural Requirements for the Ethical Economy}

The emergence and strengthening of the Ethical Economy as a core of the social knowledge society will require both material and immaterial infrastructural development.

The first is the development of a series of alternative 'corporate' structures, which are not linked to the realization of profit as a primary goal, but allow market entitities to operate for social goals, missions, purposes, etc. This is an area which we call Open Company Formats, and is a shift which is already well under way in various countries.

The second is the support to create viable "Open Business Models". These are models 
for financial resilience and sustainability that are geared towards the recognition and development, and not the suppression, of socialized knowledge pools.

The third is the development of distributed finance, both crowdfunding directly from citizens, "cloudfunding" directed to ethical finance partners, and state or public financing. An example of such financing is the 'Artistic Voucher System', which has been inscribed in the “Organic Code for Social Knowledge".

The key issue is that without the super-profits realized through Intellectual Property rents, private risk capital will be much less keen to invest in patent-free innovations, and an alternative financial system needs to be built and supported through public policy frameworks.

Thus, a new legal, pro-sharing, pro-social knowledge, infrastructure needs to be developed as well, one which supports the ethical economy and its logic, and promotes and eases the mutualization of knowledge and other immaterial resources, and of the material infrastructures of production as well. A legal infrastructure is need which promotes and develops the 'sharing', 'cooperative' and other economic forms.

A technical infrastructure will be needed, not only a generic and open internet infrastructure, but the support for the development of collaborative platforms that are appropriate for the different industrial and economic sectors. An examples are the depositories of design objects that are needed in each sector; and the infrastructure for the interconnection of smart objects, the so-called Internet of Things. An infrastructure will be needed for both open and distributed manufacturing, and for distributed production of renewable energy, close to the place of need.

New forms of open value accounting will need to be developed in order to recognize the new forms of value creation in a commons-based contributory economy.

In this context, we see the role of the Partner State as being responsible for incubating the Ethical Economy through various support policies, which may take the following institutional form:

- The Institute for the Promotion and Defense of the Commons: this is an institute which promotes the knowledge about the commons and their legal and infrastructural forms, for example, the promotion and protection for the use of Commons-Based Licenses, such as the GPL, the Creative Commons, etc .. This Institute supports the creation of common pools of knowledge, code and design, both generically and for specific sectors and regions.

- The Institute for the Incubation of the Ethical Economy, supports the emergence of 
economic practices around the common pools of knowledge. It helps the civic and ethical enterpreneurs to create livelihoods around these common pools. It teaches enterpreneurial commoners what the possibilities are to create added value around the commons, and what the legal, commercial and technical enablers are. It promotes the creation of enterpreneurial coaltions in new sectors, and supports established ethical economy players to solve common problems.

- The Transition Income: before commons can create thriving ethical economies, a period of civil engagement and investment is needed, which may not immediately yield livelihoods. Thus, a structure can be created which can materially support the creators of new common pools to sustain themselves in such transition periods. This will be a vital mechanism in combatting precarity in the early stages of commons creation, before the enterpreneurial coalitions can take up their role in the new commons economies in various sectors.

\section{The Commons-Based Civil Society. A contribution from John Restakis}

In its broadest and most accepted sense, civil society is the social impulse to free and democratic association, to the creation of community, and to the operations of social life, which includes politics. This is the sense of civil society that is used by writers such as Vaclav Havel. Civil society is distinguished from the state as it is from the operations of the private sector. Some writers also stress a distinction from the family as well.

For Havel and a long line of writers extending back to Aristotle, civil society remains the elementary fact of human existence. It is what makes human life possible. For Aristotle it was both the means and the end of human association as the pursuit of the good life, which is in essence a social life. And in this sense, it is the institutions that arise from civil society (the schools, the voluntary associations, the trade unions, the courts, the political parties, etc.) that provide the individual with the means to realize their own humanity and by so doing to perfect the whole of society in the process. The state is an outgrowth of this impulse.

As Thomas Paine wrote: "The great part of that order which reigns among mankind is not the effect of government. It has its origins in the principles of society and the natural constitution of man. It existed prior to government, and would exist if the formality of government was abolished. The mutual dependence and reciprocal interest which man has upon man, and all the parts of civilized community upon each other, create that great chain of 
connection which holds it together. In fine, society performs for itself almost everything which is ascribed to government." Alex De Toqueville, visiting America in the late seventeen famously attributed the vitality of the young democracy to the richness and diversity of its associational life.

Within civil society, a huge portion of civic activities are carried out by organizations created to provide goods and services through collaboration, by people acting together to realize mutual interests. They constitute that sector which is composed of non-profit and voluntary organizations, service groups, cultural organizations such as choral societies, charities, trade unions, and co-operatives. This economic aspect within civil society has also been described as the civil economy, the third sector or the social economy.

For all these conceptions - the commons, civil society and civil economy - the notion of reciprocity is fundamental.

\section{On reciprocity}

Reciprocity is the social mechanism that makes associational life possible. It is the foundation of social life. In its elements, reciprocity is a system of voluntary exchange between individuals based on the understanding that the giving of a favour by one will in future be reciprocated either to the giver or to someone else.

Willingness to reciprocate is a basic signal of the sociability of an individual. Taken to an extreme, the complete unwillingness of an individual to reciprocate is tantamount to severing the bonds between themselves and other people. Reciprocity is thus a social relation that contains within itself potent emotional and even spiritual dimensions. These elements account for an entirely different set of motivations within individuals than behaviour in the classical sense of "maximizing one's utility" as a consumer.

Reciprocity animates a vast range of economic activities that rest on the sharing and reinforcement of attitudes and values that are interpersonal and constitute essential bonds between the individual and the human community. What is exchanged in reciprocal transactions are not merely particular goods, services and favours, but more fundamentally the expression of good will and the assurance that one is prepared to help others. It is the foundation of trust. Consequently, the practice of reciprocity has profound social ramifications and entails a clear moral element. Reciprocity is a key for understanding how the institutions of society work. But it is also an economic principle with wholly distinct characteristics that embody social as opposed to merely commercial attributes. When 
reciprocity finds economic expression in the exchange of goods and services to people and communities it is the civil economy that results. It is in turn, a key principle underlying the formation and use of commons.

Civil economy organizations are those that pursue their goals, whether economic or social, on the basis that individuals' contributions will be reciprocated and the benefits shared. Reciprocity and mutuality are the economic and social principle that define both the activities and the aims of these organizations - whether they are co-operatives, voluntary associations, or conventional non-profits. Their primary purpose is the promotion of collective benefit. Their social product is not just the particular goods or services that they produce, but human solidarity - the predisposition of people in a society to work together around mutual goals. Another name for this is social capital. And, as opposed to the capitalist principle of capital control over labour, reciprocity is the means by which a social interest - whether it takes the form of labour, or citizen groups, or consumers - can exercise control over capital. As a sub division of civil society, the use of reciprocity for economic purposes is what distinguishes the civil or social economy from the private and public sectors.

There is no question that the long-term success of the National Plan for Good Living, and the implementation of a social knowledge economy, will rely heavily on the strength and development of a civil economy in Ecuador that is strong, autonomous, democratic, innovative, and capable of playing the central role that is assigned to it both by the constitution and the Good Living Plan itself. The civil economy is the social and economic space that most reflects the values and principles of the socialist and civic ideals of the government and the source of those civil institutions that will, in the long run, defend and advance those ideals. Lest anyone forget, it was Ecuador's civil society that gave birth to the Citizen Revolution, not the state. In the end, it will also be civil society and the vitality of its institutions that will safeguard its ideals.

For this reason, Ecuador's public policy and legislation must serve as a vital political and legal resource for building the values, skills, and institutions that enable the civil economy to flourish and to provide the indispensible social foundations that will ultimately serve to transform the political economy of the country. In our view, progressive public policy and legislation with respect to the civil economy will serve as the primary mechanism for creating a new social contract and social praxis that reflects the complementary aims and purposes of the state on the one hand and the collective values of civil society on the other. 


\section{Beyond the market, beyond planning?: the key role of Commons-Based Reciprocity Licenses}

We are making here a key strategic argument about the precise interaction between the commons and the new ethical market sectors, through the intermediation of a new type of commons-license that supports the actual emergence of a reciprocity-based ethical economy:

Indeed, the labor/p2p/commons and other social change movements today are faced with a paradox.

On the one hand we have a re-emergence of the cooperative movement and workedowned enterprises, but they suffer from structural weaknesses. Cooperative entities work for their own members, are reluctant to accept new cooperators that would share existing profits and benefits, and are practicioners of the same proprietary knowledge and artificial scarcities as their capitalist counterparts. Even though they are internally democratic, they often participate in the same dynamics of capitalist competition which undermines their own cooperative values.

On the other hand, we have an emergent field of open and commons-oriented peer production in fields such as free software, open design and open hardware, which do create common pools of knowledge for the whole of humanity, but at the same time, are dominated by both start-ups and large multinational enterprises using the same commons.

Thus, we need a new convergence or synthesis, a 'open cooperativism', that combines both commons-oriented open peer production models, with common ownership and governance models such as those of the cooperatives and the solidarity economic models.

What follows is a more detailed argument on how such transition could be achieved.

Thus, today we have a paradox, the more communistic the sharing license we use in the peer production of free software or open hardware, the more capitalistic the practice, with for example the Linux commons becoming a corporate commons enriching IBM and the like ... it works in a certain way, and seems acceptable to most free software developers, but is it the only way?

Indeed, the General Public License and its variants, allow anyone to use and modify the software code (or design), as long as the changes are also put back in the common pool under the same conditions for further users. This is in fact technically 'communism' as defined by Marx: from each according to his abilities, to each according to their needs, but which then paradoxically allows multinationals to use the free software code for profit and 
capital accumulation. The result is that we do have an accumulation of immaterial commons, based on open input, participatory process, and commons-oriented output, but that it is subsumed to capital accumulation. It is at present not possible, or not easy, to have social reproduction (i.e. livelihoods) within the sphere of the commons. Hence the free software and culture movements, however important they are as new social forces and expression new social demands, are also in essence 'liberal'. This is not only acknowledged by its leaders such as Richard Stallman, but also by anthropological studies like those of Gabriela Coleman. Not so tongue-in-cheek we could say they are liberal-communist and communist-liberal movements, which create a 'communism of capital'.

Is there an alternative? We believe there is, and this would be to replace nonreciprocal licenses, i.e. they do not demand a direct reciprocity from its users, to one based on reciprocity. Call it a switch from 'communist', to 'socialist' licenses'.

This is the choice of the Peer Production License as designed and proposed by Dmytri Kleiner; it is not to be confused with the Creative Commons non commercial license, as the logic is different.

The logic of the CC-NC is to offer protection to individuals reluctant to share, as they do not wish a commercialization of their work that would not reward them for their labor. Thus the Creative Commons 'non-commercial' license stops the further economic development based on this open and shared knowledge, and keeps it entirely in the not-forprofit sphere.

The logic of the PPL is to allow commercialization, but on the basis of a demand for reciprocity. It is designed to enable and empower a counter-hegemonic reciprocal economy that combines commons that are open to all that contribute, while charging a license fee for the the for-profit companies who want to use without contributing. Not that much changes for the multinationals in practice, they can still use the code if they contribute, as IBM does with Linux, and for those who don't, they would pay a license fee, a practice they are used to. It's practical effect would be to direct a stream of income from capital to the commons, but its main effect would be ideological, or if you like, value-driven.

The enterpreneurial coalitions that are linked around a PPL commons would be explicitely oriented towards their contributions to the commons, and the alternative value system that it represents. From the point of view of the peer producers or commoners, i.e. the communities of contributors to the common pool, it would allow them to create their own cooperative entities, in which profit would be subsumed to the social goal of sustaining the commons and the commoners. Even the participating for-profit companies would consciously 
contribute under a new logic. It links the commons to a enterpreneurial coalition of ethical market entities (coops and other models) and keeps the surplus value entirely within the sphere of commoners/cooperators instead of leaking out to the multinationals. In other words, through this convergence or rather combination of a commons model for the abundant immaterial resources, and a reciprocity-based model for the 'scarce' material resources, the issue of livelihoods and social reproduction would be solved, and surplus value is kept inside the commons sphere itself. It is the cooperatives that would, through their cooperative accumulation, fund the production of immaterial commons, because they would pay and reward the peer producers associated with them. In this way, peer production would move from a proto-mode of production, unable to perpetuate itself on its own outside capitalism, to a autonomous and real mode of production. It creates a counter-economy that can be the basis for reconstituting a 'counter-hegemony' with a for-benefit circulation of value, which allied to pro-commons social movements, could be the basis of the political and social transformation of the political economy. Hence we move from a situation in which the communism of capital is dominant, to a situation in which we have a 'capital for the commons', increasingly insuring the self-reproduction of the peer production mode.

The PPL is used experimentally by Guerilla Translations! and is being discussed in various places, such as for example, in France, in the open agricultural machining and design communities.

There is also a specific potential, inside the commons-oriented ethical economy, such as the application of open book accounting and open supply chains, would allow a different value circulation, whereby the stigmergic mutual coordination that already works at scale for immaterial cooperation and production, would move to the coordination of physical production, creating post-market dynamics of allocation in the physical sphere. Replacing both the market allocation through the price signal, and central planning, this new system of material production would allow for massive mutual coordination instead, enabling a new form of 'resource-based economics'

Finally, this whole system can be strengthened by creating commons-based venture funding, so as to create material commons, as proposed by Dmytri Kleiner. In this way, the machine park itself is taken out of the sphere of capital accumulation. In this proposed system, cooperatives needing capital for machinery, would post a bond, and the other coops in the system would fund the bond, and buy the machine for a commons in which both funders and users would be members. The interest paid on these loans would create a fund that would gradually be able to pay an increasing income to their members, constituting a new kind of 
basis income.

The new open cooperativism is substantially different from the older form. In the older form, internal economic democracy is accompanied by participation in market dynamics on behalf of the members, using capitalist competition. Hence a unwillingness to share profits and benefits with outsiders. There is no creation of the commons. We need a different model in which the cooperatives produce commons, and are statutorily oriented towards the creation of the common good, with multi-stakeholders forms of governance which include workers, users-consumers, investors and the concerned communities.

Today we have a paradox that open communities of peer producers are oriented towards the start-up model and are subsumed to the profit model, while the cooperatives remain closed, use IP, and do not create commons. In the new model of open cooperativism, a merger should occur between the open peer production of commons, and the cooperative production of value. The new open cooperativism integrates externalities, practices economic democracy, produces commons for the common good, and socializes its knowledge. The circulation of the common is combined with the process of cooperative accumulation, on behalf of the commons and its contributors. In the beginning, the immaterial commons field, following the logic of free contributions and universal use for everyone who needs it, would co-exist with a cooperative model for physical production, based on reciprocity. But as the cooperative model becomes more and more hyper-productive and is able to create sustainable abundance in material goods, the two logics would merge.

\section{Mutual coordination mechanisms in the new 'ethical' enterpreneurial coalitions: Cybersyn $^{2}$ redux ?}

Traditional economic debates are often between the options of state-initiated planning on the one side, and the allocation through market pricing signals on the other hand. But the social knowledge economy shows the increasing likely path of a third method of allocation, that of transparent mutual coordination. The first attempt to such a type of resource-based economy, in the Soviet Union of the 1960's, when the construction of a proto-internet was initiated, is well documented in the book by Francis Spufford, Red Plenty. The effort failed because the opposition of the bureaucratic forces in the state apparatus. The second attempt took place in Allende's Chile in the early seventies, under the advise and leadership of complexity thinker Stafford Beer, and was successfully used on a smaller scale to overcome a

\footnotetext{
${ }^{2}$ Cybersyn was a democratic planning / mutual coordination project for Chilean industry, undertaken by Stafford Beer for the government of Salvador Allende, you can find details here at http://p2pfoundation.net/ Cybersyn
} 
cripling strike of the transportation industry, where with $25 \%$ of the fleet, and using telexes for coordination, the strike was overcome. Thus the project Cybersin was born, a project to mutually and democratically coordinate Chilean industry, but the project was destroyed through the military coup, and the effective bombing of its headquarters.

Nevertheless, under the impulse of the social knowledge communities, mutual coordination of complex activities is making a very strong appearance, even if it is limited at present to the production of 'immaterial' value, i.e. knowledge products. This emergence nevertheless has implications for a transition to a new type of economic coordination, that will co-exist with both state planning, which received a strong impulse in Ecuador, and traditional market pricing mechanisms.

Indeed, the really-existing social knowledge economy of commons-oriented peer production of free software, open design and hardware, is known to function according to the principle of mutual coordination, or "stigmergy". The open design communities that already exist construct and coordinate their construction of common pools of knowledge, code, and design, through mutual signalling systems because their infrastructures of cooperation are fully open and transparent.

In the world of physical production, we can see an emergence of open supply chains and open book accounting on a much smaller scale. Nevertheless, there is a historical opportunity for a emergence of mutual coordination of physical production, if the 'ethical enterpreneurial coalitions', which may emerge around the social knowledge economy, decide to share their accounting and logistical information streams, within those coalitions. In this scenario, which is hypothetical at present but could be an integral part of a mature p2p/commons oriented social knowledge economy, we would see the gradual emergence of a third way for the coordinated allocation of resources for economic production. 


\section{REFERENCES}

ARROW, K. Economic welfare and the allocation of resources for invention. In: ARROW, K. (Ed.). The Rate and Direction of Inventive Activity : economic and social factors. Princeton: Princeton University Press, 1962. p. 609-625.

ARVIDSSON, Adam; PEITERSEN, Nicolai. Rebuilding value after the crisis. Nova Iorque: Columbia University Press, 2013.

BARANDIARAN, Xabier E.; VÁZQUEZ, Daniel. Devenir sociedad del conocimiento común y abierto. Sumak Yachay: Designing the FLOK Society, Quito, v. 15, n. 2, p.1-22, 2013.

BELFANTI, Carlo Marco. Guilds, patents, and the circulation of technical knowledge: northern Italy during the early modern age. Technology And Culture, Baltimore, v. 45, n. 3, p.569-589, jul. 2004. Disponível em:

<https://muse.jhu.edu/journals/technology_and_culture/v045/45.3belfanti.pdf > . Acesso em: 27 ago. 2014.

BERNERS-LEE, Tim. Weaving the web: the original design and ultimate destiny of the World Wide Web by its inventor. São Francisco: Harpersanfrancisco, 1999.

BOLDRIN, Michele ; LEVINE, David K. NUVOLARI, A. Do Patents Encourage or Hinder Innovation? The Case of the Steam Engine. The Freeman, Nova Iorque, p.14-17, out. 2008. BOLDRIN, Michele ; LEVINE, David K. The case against patents. Journal of Economic Perspectives, Pitsburgo, v. 27, n. 1, p.3-22, 2013. Disponível em:

<http://pubs.aeaweb.org/doi/pdfplus/10.1257/jep.27.1.3>. Acesso em: 02 set. 2014.

ASIDE, Eric. NIHilism and other innovation poison. 2008. Disponível em:

$<$ http://blogs.msdn.com/b/eric_brechner/archive/2008/11/01/nihilism-and-other-innovationpoison.aspx>. Acesso em: 02 set. 2014.

BURROUG, Xtine (Ed.). Net works: case studies in web art and design. Londres; Nova Iorque: Routledge, 2012.

DOSI, G.; MARENGO, L. How much should society fuel the greed of innovators? on the relations between appropriability, opportunities and rates of innovation. Research Policy: policy, management and economic studies of science, technology and innovation, Lund, v. 35, n. 8, p.1110-1121, out. 2006. Disponível em: <http://www.sciencedirect.com/science/article/pii/S0048733306001399>. Acesso em: 02 set. 2014. 
GATES, Bill. Bill Gates memo of 5-16. [mensagem pessoal] Mensagem recebida por: <eniac@mejac.palo-alto.ca.us>.em: 2 jul. 1991. Disponível em: < http://www.std.com/obi/Bill.Gates/Challenges.and.Strategy>. Acesso em: 02 set. 2014.

GILFILLAN, S. Colum. Inventing the ship: a study of the inventions made in her history between floating log and rotorship. Chicago: Follett Publishing Company, 1935.

GILFILLAN, S. Colum. The sociology of invention: an essay in the social causes, ways, and effects of technic invention, especially as demonstrated historicly. Cambridge: M.I.T Press, 1970.

LEVIN, Richard C. et al. Appropriating the returns from industrial research and development. Brookings Papers on Economic Activity, Washington, v. 18, n. 3, p.783-831, 1987. Disponível em: <http://www.brookings.edu/ /media/projects/bpea/1987 3/1987c_bpea_levin_klevorick_nelson_winter_gilbert_griliches>. Acesso em: 02 set. 2014.

LEVY, S. Hackers: heroes of the computer revolution. New York:Anchor Press:Doubleday, 1984.

MANN, Charles C.; PLUMMER, Mark L. The aspirin wars: money, medicine, and 100 years of rampant competition. Nova Iorque: Knopf, 1991.

MOSER, Petra. Patents and innovation: evidence from Economic History. Journal of Economic Perspectives, Pitsburgo, v. 27, n. 1, p.23-44, 2013.

NUVOLARI, Alessandro. The making of steam power technology: a study of technical change during the british industrial revolution. The Journal of Economic

History,Cambridge, v. 66, n. 2, p.472-476, jun. 2006. Disponível em:

<http://www.jstor.org/stable/3874887?origin=JSTOR-pdf>. Acesso em: 02 set. 2014.

PEARCE, Joshua M. Physics: make nanotechnology research open-source. Nature, [S. 1.], v. 491, p.519-521, 22 nov. 2012. Disponível em:

<http://www.nature.com/nature/journal/v491/n7425/pdf/491519a.pdf>. Acesso em: 02 set. 2014.

PEARCE, Joshua M.. The case for open source appropriate technology. Environment, Development And Sustainability, Houghton, v. 14, n. 3, p.425-431, jun. 2012. Disponível em: 〈http://link.springer.com/article/10.1007/s10668-012-9337-9>. Acesso em: 02 set. 2014.

SCHOLZ, Trebor. Cheaper by the dozen. In: BURROUGH, Xtine (Ed.). Net works: case studies in web art and design. Nova Iorque; Londres: Routledge, 2012. p. 47-54.

SCOTCHMER, Suzanne. Standing on the shoulders of giants: cumulative research and the patent law. Journal of Economic Perspectives, Pittsburg, v. 5, n. 1, p.29-41, 1991. 
WARK, Mckenzie. The hacker manifesto. Cambridge: Harvard University Press, 2004.

ZIEDONIS, Rosemarie Ham ; HALL, Bronwyn H. An empirical analysis of patent litigation in the semiconductor industry. Econometrics Laboratory, Berkeley, p.1-30, 2007. Disponível em:

$<$ http://citeseerx.ist.psu.edu/viewdoc/download?doi=10.1.1.69.5271\&rep=rep1\&type=pdf $>$. Acesso em: 02 set. 2014. 